Article

\title{
A Supply Chain Approach to Trade and Labor Provisions
}

\author{
Kevin Kolben \\ Rutgers Business School, Rutgers University, Newark, NJ 07102, USA; E-Mail: kkolben@business.rutgers.edu
}

Submitted: 1 July 2017 | Accepted: 28 August 2017 | Published: 14 December 2017

\begin{abstract}
As labor provisions in trade agreements have become increasingly ubiquitous, there remain questions about whether or not these provisions have been effective in improving working conditions in trading partner countries. Through an analysis of sample labor provisions in United States and European Union free trade agreements, this paper shows that both approaches, albeit using different methods, aim primarily to improve de jure labor law and de facto enforcement of that law by government regulatory institutions. This paper argues that instead, labor provisions ought to be grounded in a supply chain approach. A supply chain approach shifts the focus from impacting de jure and de facto labor law as administered by the state though sanctions or dialogue, and towards context specific, experimental, and coordinated private and public regulatory interventions that operate in key export industries that are implicated in trading partners' supply chains. It does so in part by recognizing the potential regulatory power of consumer citizenship.
\end{abstract}

\section{Keywords}

consumer citizenship; governance; labor provisions; supply chains; trade

\section{Issue}

This article is part of the issue "Labour Standards in a Global Environment", edited by Gerda Van Roozendaal (University of Groningen, The Netherlands) and Jan Orbie (Ghent University, Belgium).

(C) 2017 by the author; licensee Cogitatio (Lisbon, Portugal). This article is licensed under a Creative Commons Attribution 4.0 International License (CC BY).

\section{Introduction}

Labor provisions have become increasingly common in bilateral and regional free trade agreements (FTAs) across the globe. Utilizing varying mechanisms, these provisions seek to ensure that labor conditions in workplaces connected to global trade adequately respect international core labor rights and domestic labor law. Indeed, according to the International Labor Organization (ILO), it is now more unusual not to include labor provisions than to include them. The ILO (2016) states that as of December 2015 there were 76 trade agreements, covering 135 countries, that included labor provisions. Over half of these agreements were concluded post-2008, and over $80 \%$ of all FTAs that came into force since 2013 contain labor provisions (ILO, 2016, p. 1). This growth in labor rights conditionality and promotion has been paralleled in investment agreements, where 12 out of the 31
International Investment Agreements concluded in 2014 refer to the protection of labor rights, including ILO instruments (ILO, 2016, p. 2).

The United States (US) has been a pioneer in these efforts. Labor provisions have been a core element of its trade agenda since the 1980s, with the incorporation of labor conditionality in its Generalized System of Preferences scheme. ${ }^{1}$ In the European Union (EU), labor provisions have been part of trade policy since 1995, playing a significantly greater role in 2008 with the CARIFORUM agreement (De Ville, Orbie, \& Van den Putte, 2016, p. 22). The two approaches differ. The US approach is grounded in a state action-state sanctions model that requires a) de jure changes in labor law, and b) de facto enforcement of those laws, violation of which is subject to dispute settlement and sanctions. The EU's model, on the other hand, is grounded in a promotional or cooperative approach (De Ville et al., 2016, pp. 16-17), that aims to

\footnotetext{
${ }^{1}$ In 1987, Congress included labor conditionality in the Generalized Systems of Preferences program, requiring that the president determine that a recipient country has "taken steps" towards "affording internationally recognized workers rights" to its citizens. In its regional and bilateral free trade agreements, it first included a side agreement on labor in NAFTA, its free trade agreement with Mexico and Canada.
} 
export norms, primarily through incentives and dialogic institutions (Orbie, 2011, p. 180). Its primary tools are thus not threat of sanctions, but rather social dialogue. Both of these models have come under intense scrutiny, however, by a number of scholars who argue that as a whole, they have been either ineffective at improving working conditions in trading partner countries, or are effective in only limited ways (Brown, 2015; Giumelli \& Van Roozendaal, 2016; Orbie \& Van den Putte, 2016; Van Roozendaal, 2015; Vogt, 2015). The proposed solutions to this problem vary, and some scholars recognize that there is no one size fits all solution and that converting labor provisions into real improvements in labor rights and standards is complex and dependent on a number of factors (Giumelli \& Van Roozendaal, 2016). But many of the critiques, particularly from trade union activists, argue that the key to improving the effectiveness of these agreements is to strengthen the dispute settlement procedures and arm them with bigger and better sticks that are used with greater frequency, i.e. applying harsher sanctions.

This paper takes a different approach. It argues that both the US and the EU models as currently designed are limited in their ability to achieve sustainable de jure and de facto improvements in labor standards in their trading partner countries, but not primarily because of their weak sanctioning power. Instead, this paper argues that trade and labor chapters ought to adopt a supply chain governance approach. A supply chain governance approach shifts the current focus of labor chapters from broadly affecting de jure and de facto labor law through the use of sanctions or dialogue, towards context specific and coordinated private and public regulatory interventions that focus on improving labor rights and standards in key export industries. Such experimental regulatory tools are rooted in what some scholars describe as governance, or sometimes "new governance" approaches to regulation (Van Den Putte \& Orbie, 2015). Just as firms have increasingly responded to consumer and civil society pressure to supplement inadequate state labor regulation through private supply chain governance, labor provisions should build on these social and market dynamics. That means developing governance based institutions that draw on tools of consumer citizenship to achieve their stated goals of improving labor conditions and respecting labor rights. In other words, to solve a supply chain problem, we need supply chain solutions.

\section{The EU and US Legal Frameworks}

Before proposing a new framework, we must first describe the extant models that it would replace, focusing on the examples of the US and EU. The EU and US use different tools to achieve their stated goals, reflecting in part differing philosophies. Both of these models are primarily rooted in a traditional approach to interna- tional relations and law that seeks to influence the de jure and de facto conduct of state actors, through means that Oehri (2015, pp. 734-735) describes as both "hierarchical", i.e. political and judicial enforcement, and "networked", i.e. assistance and collaboration.

\subsection{The US Approach}

The US approach to its labor chapters can be described as a state action-state sanctions model (Kolben, 2007). The primary aim and tools of such a model is to change a trading partner country's de jure labor laws, and to improve their de facto enforcement (Vogt, 2015). The US model has gone through several iterations over time, beginning with the NAFTA side agreement on labor cooperation, and evolving into a model adopted as per an agreement between the Bush administration and Congress on May 10, 2007, known generally as the May 10 agreement (Bolle, 2016). Each new generation of labor chapter has iteratively strengthened its requirements and enforcement provisions.

Here, we will use the Trans-Pacific Partnership agreement ${ }^{2}$ (TPP) as our primary object of analysis to illustrate the US model. This is because it was the latest labor chapter that was negotiated, and even though the Trump administration subsequently withdrew from the TPP, it a) still serves as a model for what might come ahead, and b) reflects the policy assumptions that have informed US labor chapters heretofore. However, it also increasingly utilized dialogue and other non-sanctions methods that have been more typically associated with the EU model.

Labor provisions function in two stages: Pre-ratification, and post-ratification. During the pre-ratification stage, states will agree formally or informally to make specific changes to their labor laws as a condition for signing the FTA. According to some scholars, it is at this stage that labor provisions have been most effective in fostering real reform (Kim, 2012; Vogt, 2015). The TPP effectively formalized the pre-ratification improvement process by including three formal agreements, called Labour Consistency Plans (LCP). These were concluded with Vietnam, Malaysia, and Brunei. The Vietnam LCP focused on Vietnam's restrictions on independent grass roots unions, and required that Vietnam allow such unions to operate and self-govern. This would have brought Vietnam into compliance with ILO standards, as well as come closer into compliance with US expectations of how an industrial relations system should be organized. The Malaysia LCP called on Malaysia to ban the withholding of migrant worker passports, ban the payment of recruitment fees by workers, and reduce government discretion in registering trade unions. The Brunei LCP called on the country to, for example, implement nondiscrimination laws and enact a minimum wage.

The second way in which labor provisions function is during the post-ratification stage by utilizing the in-

\footnotetext{
2 Trans-Pacific Partnership, signed on February 4, 2016, withdrawn by the US on January 23, 2017. Full text available at https://ustr.gov/tradeagreements/free-trade-agreements/trans-pacific-partnership/tpp-full-text
} 
stitutions provided for in the labor provision. Here, the TPP adopted and slightly strengthened the labor chapters that came before it, requiring that the parties "adopt and maintain in its statutes and regulations the...[core labor] rights as stated in the ILO Declaration" (TPP, Art. 19.3.1), ${ }^{3}$ and that "each Party shall adopt and maintain statutes and regulations, and practices thereunder, governing acceptable conditions of work with respect to minimum wages, hours of work, and occupational safety and health" (TPP, Article 19.3.2).

The second leg of the US model is a non-derogation clause, which provides that, "no party shall fail to effectively enforce its labor laws through a sustained or recurring course of action or inaction in a manner affecting trade or investment between the Parties after the date of entry into force of this Agreement" (TPP, Art. 19.5.) This proviso attempts to incentivize adequate de facto enforcement of a party's labor laws, which of course are supposed to comply with the de jure requirements.

The third leg is the dispute settlement provision. While the labor chapter is subject to the general dispute settlement provisions of TPP, the parties must first engage in a consultative process, known as labor consultations (TPP, Art 19.15.2). If the parties cannot resolve the issue within sixty days through consultations or through other consultative mechanisms available to them, then the "requesting party" may begin general dispute settlement procedures (TPP, 19.15.8-10).

But the TPP also makes efforts to increase reliance on dialogue and cooperation that brings it closer to the EU model, which we will examine below, and that also opens the door to alternative and experimental mechanisms of supply chain governance. For example, as an effort to encourage dialogue over conflict, the TPP provides a mechanism outside of dispute settlement that is new for US FTA labor chapters known as "cooperative labour dialogue" (TPP, Art. 19.11). If a party chooses to initiate dialogue under this section on any matter arising out of the chapter, the parties shall commence dialogue within 30 days (TPP, 19.11.3) and the parties shall address all the issues in the request (TPP, Art. 19.11.5), "receiving and considering views of interested parties in the matter" (TPP, Art. 19.11.3). One way that the agreement provides that the parties may address the raised issues is through "independent verification of compliance or implementation by...entities, such as the ILO" (TPP, Art. 19.11.6(b)). This provision differs from earlier labor chapters in that the emphasis is on dialogue, and is not a necessary precursor to, or constituent element of, dispute settlement procedures.

The TPP also promotes and provides for various kinds of engagement and dialogue with the public. Article
19.14, for example, provides that the Labour Council shall "provide a means for receiving and considering the views of interested persons on matters related to this Chapter". It then also provides that each Party "shall establish or maintain, and consult, a national labor consultative or advisory or similar mechanism, for members of its public, including representatives of its labor and business organizations, to provide views on matters regarding this Chapter" (TPP, 19.14(2)).

The TPP also hints at an openness to methods beyond the traditional state action-state sanctions model in other ways. For example, one article calls for each party to "encourage enterprises to voluntarily adopt corporate social responsibility initiatives on labor issues that have been endorsed or are supported by that party" (TPP, Art. 19.7). This is a non-binding obligation that establishes a promotional framework for companies within each party's jurisdiction, whether it be lead firms or suppliers, to take action above and beyond what they might be legally obligated to do. Thus any pressure for companies to act or "self-regulate", would have to emanate from consumers and other stakeholders. We will return to that topic in Part 3, for it is key in developing a supply chain approach to trade and labor provisions.

\subsection{The EU Approach}

While the US model is primarily grounded in a state action-state sanctions approach with increasing reliance on dialogue, the EU approach might be termed at state action-social dialogue approach. That is, while the focus of the labor chapter is on the law and conduct of states, the means of improving labor standards in partner countries is through a "promotional" mechanism (Campling, Harrison, Richardson, \& Smith, 2016). The EU is not alone in adopting a promotional strategy, for some $40 \%$ of trade agreements, according to the ILO use such an approach (Campling et al., 2016, p. 361).

The EU's model differs in several ways from the US model both in its general framework as well as its institutions. As we used the non-implemented TPP as an example of the US approach, we will use the implemented EU-Colombia and Peru Agreement, ${ }^{4}$ to which Ecuador acceded in 2017, as our EU model (EU-Colombia). ${ }^{5}$ One significant difference from the US model is that the labor provisions in EU agreements are found in a chapter entitled Trade and Sustainable Development that treats not just labor but also environmental issues. The agreement provides that, "each party commits to the promotion and effective implementation in its laws and practices" of the fundamental ILO conventions (EU-Colombia, Art. 269). To achieve this, the same article discusses the impor-

\footnotetext{
${ }^{3}$ Like in previous agreements, these rights are explicitly limited to those stated in the declaration, which is noted by a number of scholars to be an effort not to specifically link them to any requirements to adopt the correlated eight ILO conventions, of which the US has only ratified two (Brown, 2015, pp. 387-388).

4 Trade Agreement between the European Union and its Member States, of the one part, and Colombia and Peru, of the other part, EU-Colombia-Peru, on June 26, 2012, 2012 O.J. (L 354) 3.

${ }^{5}$ Although the EU has more variation in its agreements than does the US, most of the "new generation" FTAs follow a similar blueprint. (Campling et al., 2016, p. 363)
} 
tance of "dialogue" (EU-Colombia, Art. 269.2), information exchange (EU-Colombia, Art. 269.4), and emphasizes that labor standards should not be used for protectionist ends (EU-Colombia, Art. 269.5).

Like the US model, the EU FTA has a non-derogation clause, whereby a) "no party shall encourage trade or investment by reducing the levels of protection afforded in its...labour laws" (EU-Colombia, Art. 277.1), and b) "a party shall not fail to effectively enforce...its labour laws through a sustained or recurring course of action or inaction in a manner affecting trade or investment between the parties" (EU-Colombia, Art. 277.2). This language is very similar to the US model. The main difference is that the US model as manifested in the TPP requires that the parties not derogate from enforcing ILO core labor rights or laws related to minimum wages, hours of work, and occupational health and safety (TPP, Art. 19.3-19.4), which the EU approach does not do.

While the substantive requirements are not very dissimilar, the institutional and enforcement mechanisms diverge quite a bit. The EU agreement provides for an institutional and monitoring mechanism that emphasizes dialogue and a collaborative relationship. First, it establishes a subcommittee on trade and sustainable development that oversees implementation of the trade and sustainability provision of the agreement (EU-Colombia, Art. 280.4). Its work is to be "based on dialogue, effective cooperation...and...mutually satisfactory solutions" (EU-Colombia, Art. 280.5). A primary aim of the subcommittee is to "promote transparency and public participation", and its output it to be shared publicly and be subject to public comment (EU-Colombia, Art. 280.7). Once a year, the subcommittee is mandated to meet and to hold a "dialogue with civil society organizations and the public at large" on matters related to trade and sustainability (EU-Colombia, Art. 282). To ensure representation and ongoing consultation and dialogue, a second cooperative and dialogue based institution is provided for, Domestic Advisory Groups (DAGs). These groups are meant to be mechanisms that provide ongoing input to their relevant governments (EU-Colombia, Art. 281). The DAGs are required to have a "balanced representation of representative organizations" (EU-Colombia, Art. 281), and all the stakeholders that are meant to constitute DAGs have a right to participate in the yearly public committee meeting (EU-Colombia, Art. 282.2). Like the US labor chapters, the EU promotes its cooperative approach in a separate section that "recognizes the importance of cooperation activities", delineates those areas, and explicitly notes the importance of certification schemes (EU-Colombia, Art. 286(g)) and of "good practices of corporate social responsibility" (EU-Colombia, Art. 286(j)).

The EU approach to disputes differs from the US approach primarily in that there is no resort to dispute settlement procedures at all. It is here that a number of commentators have been particularly critical of the EU (Bartels, 2017). Instead, if there is a conflict, as in the US model, there are to be consultations between the parties (EU-Colombia, Art. 283). If this does not resolve the matter, then the Committee may be convened (EU-Colombia, Art. 283.3), and the subcommittee "shall periodically publish reports" about the process and outcomes of the consultations (EU-Colombia, Art. 283.4). If the parties can't resolve the matter within 90 days (EU-Colombia, Art. 284.1), a group of experts is selected by the parties that after a delineated period of time issues a final report (EU-Colombia, Art. 285.2). A non-confidential version of this report must then be made public. Adherence and compliance basically relies on "naming and shaming", because the parties must be persuaded, educated, or perhaps pressured by the public after the report's release for there to be corrective action taken.

\subsection{Comparison}

As some scholars have argued, the differences between the US and EU models might be more in form than in substance (Van Den Putte \& Orbie, 2015). Both, for the most part, rely on the ILO core labor standards as the benchmark standard, although the US in its TPP labor chapter created a minimalist requirement to enact laws related to non-core standards. Both the EU and US approaches emphasize dialogue and cooperation though various institutions and processes of stakeholder engagement, although the EU is more explicit in this regard, as shown above. While the US approach provides for sanctions in case a mutually agreeable solution cannot be achieved, the stick of sanctions can only be utilized after a consultative process. Finally, some have argued that while the US model does provide for the possibility of sanctions if there is found to be a violation of the labor chapter by an arbitration panel, the report issued by the group of experts in the EU model serves a similar function as the arbitration panel, but just without the big stick. (Van Den Putte \& Orbie, 2015, pp. 269-270).

A number of commentators have argued that a core failure of both the EU and the US models is that the lack of sticks in the EU model (Bartels, 2017), and the lack of adequate utilization of those sticks in the US model has led to them being ineffective (Vogt, 2015). While the US has a more vigorous dispute settlement procedure on paper, it is argued, in fact it has been seldom used, and resolution of complaints has taken years (Van Roozendaal, 2015). Van Roozendaal (2015) notes that in Guatemala, for example, that despite the initiation of a complaints procedure against it and the risk of sanction, Guatemala has made little progress in reforming its labor laws to bring them into conformity with international law, or Guatemala's practices. ${ }^{6}$ One reason for this, according to Van Roozendaal (2015, p. 21), is because of

\footnotetext{
${ }^{6}$ Guatemala was primarily accused in the complaint of violations of freedom of association rights under ILO Conventions 87 and 98 , including violence against trade union leaders.
} 
the weakness of the sanctions mechanism in the CAFTADR agreement, which capped fines at $\$ 15$ million - not a sum that is likely to incentivize action on its own.

Other scholars, however, argue that the EU's dialogue based approach is in fact productive, leading to improved workers' rights outcomes in partner countries. Postnikov and Bastiaens (2014, pp. 927-928), for example, argue that civil society actors in trading partners learn from their EU counterparts how to pressure state actors to improve labor rights enforcement. The ILO has concluded that one of the more successful aspects of trade agreements has been the multi-stakeholder institutions, leading to increase public awareness of labor issues, enhanced social dialogue, and increased ability to put labor issues on the political agenda (ILO, 2016, pp. 39-40).

Another potential problem with both models is that they require the political will of governments to enforce them. Non-state actors do not have the right to bring complaints against, or start dialogue with, other governments; only the state parties themselves do. ${ }^{7}$ Thus as Vogt (2015, p. 859) notes, given this fact, "the agreements will only be as useful as politicians desire them to be". Indeed, despite extreme abuses found in Jordan's garment industry, the US declined to trigger the dispute settlement process provided for in the US-Jordan FTA's labor chapter (Kolben, 2013). Adopting a similar rationalist argument, Van Roozendaal (2015) argues that enforcement is only likely to occur, not from a commitment to labor rights, but rather as a means of securing support for more FTAs in the future. To address this some scholars have argued that a third party complaint mechanism that eliminates government discretion might resolve this political will problem (Brown, 2015, p. 398). Indeed, according to the US Department of Labor, of the seven submissions that have been accepted for review under the trade and labor chapters since 2007, only one has gone to an arbitral panel, the Guatemala case, discussed above. And despite great hopes by trade unions and labor activists, the arbitral panel found in favor of Guatemala. ${ }^{8}$

\section{A Supply Chain Approach to Trade and Labor Provisions}

So given the somewhat grim and sometimes conflicting assessments of the effectiveness and achievements heretofore of labor provisions in FTAs, is there an alternative or perhaps complementary path forward? It is suggested here that there is. The argument is that trade and labor provisions should not focus uniquely on impacting de jure and de facto state action broadly construed, as they do now, but rather be tailored to en- sure that the working conditions and core labor rights protections in each other's supply chains meet the expectations of each other's citizenry. As Campling et al. (2016, p. 366) have posed the question, should labor provisions "seek to promote overall improvements in labor standards in third countries, or focus only on key export industries"? The suggestion here is that they should emphasize the latter, drawing on the leverage of consumer citizens and the regulatory tools of governance and democratic experimentalism.

\subsection{Consumer Citizenship}

To understand how a supply chain approach to labor chapters could potentially be effective, we need to understand consumer citizenship. Consumer citizenship is the notion that consumers exercise and express political preferences through their consumptive choices (Johnston, 2008; Stolle \& Micheletti, 2013) It is the "use of the market as an arena for politics in order to change institutional or market practices found to be ethically, environmentally, or politically objectionable" (Stolle \& Micheletti, 2013, p. 39)..$^{9}$ Consumer citizens make consumptive choices based on a set of ethical or other criteria that provides meaning for them. They can "buycott", meaning rewarding certain companies by favoring them in their purchases, and/or boycott, by punishing bad actors by refusing to buy from them and encouraging others to do the same (Stolle \& Micheletti, 2013, p. 40).

According to Stolle and Michelleti (2013, p. 97), about $31 \%$ of all people report engaging in either buycotting, boycotting, or both. In Sweden, for example, approximately $60 \%$ of respondents report doing so, while by contrast in the US, some $28 \%$ report doing so (Stolle \& Micheletti, 2013, p. 97). The dramatic rise in popularity of so called Fair Trade branded goods is one manifestation of this (Fairtrade International, 2016; Nicholls, 2010), and experimental research has suggested that in certain conditions, particularly for higher cost items, consumers are willing to pay more for clothing and grocery store items that are labeled as being made in better conditions (Hainmueller \& Hiscox, 2015; Hainmueller, Hiscox, \& Sequeira, 2015). Consumer demand for socially compliant goods is also reflected in the degree to which lead firms have implemented codes of conduct in their supply chains and have joined various multi-stakeholder initiatives (Locke, 2013). Over 9,000 companies have joined the Global Compact, for example, which requires a public commitment to its 10 principles, including a commitment to human rights and internationally recognized core labor rights and reporting on how those principles are embedded in their operations. ${ }^{10}$ The recog-

\footnotetext{
${ }^{7}$ Instead, individuals may make submissions to the parties, which are then considered, and then may at the discretion of the parties be considered for review and then brought as a consultation or complaint against another party to the agreement.

${ }^{8}$ In the Matter of Guatemala-Issues Relating to the Obligations Under Article 16.2.1(a) of the CAFTA-DR, final report of the panel, June 14, 2017.

${ }^{9}$ Scholars have alternatively termed this phenomenon political consumerism, (Stolle \& Micheletti, 2013) ethical consumption (Eckhardt, Belk, \& Devinney, 2010), and conscientious consumerism (Bartley, Koos, Samel, Setrini, \& Summers, 2015).

10 The Global Compact, the Ten Principles of the UN Global Compact, available at https://www.unglobalcompact.org/what-is-gc/mission/principles; also, the UN Global Compact, Communication on Progress: An Introduction (2015), available at https://www.unglobalcompact.org/docs/communication_on_ progress/Intro_to_COP.pdf
} 
nition of consumer citizenship's potential as a political and market factor could be better utilized in labor provisions design.

\subsection{Experimental Labor Provisions}

If global citizen consumers are increasingly interested in purchasing goods that they can be ensured were made in conditions that meet their social preferences, then to capitalize on this, labor provisions should create institutions that target the supply chains to which consumer citizens have a direct connection. Bolstering the quality of a country's labor regulatory regime is a worthy but very ambitious project. But we have seen that labor provisions have not been particularly successful in achieving that goal. The reasons for domestic regulatory weakness are highly complex, and are contingent on a broad set of factors, including democratic functioning, economic development, and complex dimensions of rule of law. A labor rights clause grounded in state to state dialogue or even sanctions is a poor tool to address these highly complex problems. The aims and goals of labor provisions as they are currently conceived might thus be too broadly targeted to achieve concrete improvements in actual workplaces that are directly connected to the economies and citizens of the trading partner countries. This squanders an opportunity.

Accordingly, it is argued here that a better way is a tailored supply chain approach that draws on the insights of governance theory and democratic experimentalism (Kolben, 2015; Sabel \& Zeitlin, 2008). Broadly speaking, governance and democratic experimentalism recognize the limitations of centralized legal decision making, and look to alternative mechanisms of decentered governance that promote deliberation, experimentation, benchmarking, transparency, and best practice to build effective, bottom up systems of governance (Black, 2008). In some forms, legal interventions are used to spark reflexive systems of self-regulation (Rogowski, 2013). Governance based regulatory approaches can be particularly well suited to developing countries, where regulatory capacity is already weak, and can be complemented by non-state regulatory tools.

Some scholars have argued that the EU's use of dialogue and cooperation is already complementary to a governance model (Campling et al., 2016; Van Den Putte \& Orbie, 2015). In fact, the same could be said of the US regime, as well. It, too, attempts to generate dialogue and cooperation between the parties and provides for stakeholder engagement. And there is nothing in the US model that excludes the addition of a provision that would specify a set of institutions that would be oriented towards an experimentalist and governance approach. Campling et al. (2016, p. 360) claim that, "we are currently witnessing a period of experimentation whereby different models of labor provisions are operating in bilateral trade agreements between different trading partners. These models differ greatly in terms of scope of trade, scope of labor provisions, methods of promotion and methods of enforcement".

But the extent to which this is occurring is arguable. While there might be variety in methods and processes utilized in different agreements, by and large they all draw upon the same toolkit, which include effective enforcement and implementation of laws, adherence to international labor standards, non-derogation from those standards, and some forms of stakeholder engagement (ILO, 2016, p. 10). Instead, a truly experimental approach would be more micro based, and build on the cooperative and dialogue based instruments that have been developing in the various labor provisions models. For example, in the TPP, Article 19.7 calls for each party to "encourage enterprises to voluntarily adopt corporate social responsibility initiatives on labour issues that have been endorsed or are supported by that party". In the EU-Colombia Agreement (Art. 271.3), "the Parties agree to promote best business practices related to corporate social responsibility", and to "exchange information...related to the promotion...of good practices of corporate social responsibility..." (EU-Colombia, Art. 286(j)).

Policymakers should use the principles of Corporate Social Responsibility (CSR), dialogue and cooperation that are thinly specified in the agreements, and make them thick through actual institutions that can draw on the dynamics of consumer citizenship described earlier. The test for their effectiveness should not be whether there will be wholesale change in the politics and enforcement of labor law in a regime in which there is general and wholesale weak rule of law, but rather if there has been specific, measurable labor standards and rights improvements in the relevant supply chains.

But this is hardly to say one should just forget about the state. On the contrary, by focusing more on the micro level than labor provisions currently do, the broader goals of macro level improvements in labor law enforcement could also be achieved. How might this be accomplished? While a longer discussion of how these dynamics might operate is beyond the scope of this paper, scholars have begun investigating the ways that private regulation can interact with and sometimes reinforce or bolster state regulation (Amengual \& Chirot, 2016; Dupper, Fenwick, \& Hardy, 2016; Kolben, 2015). Moreover, it is also important to emphasize that the experimental approaches argued for here are not the same as CSR, soft law, or other purely private mechanisms. Rather, they draw on public and private tools of regulation with the explicit goal of strengthening public regulatory capacity. The task then is to draw on the insights of regulatory scholars and re-orient labor provisions towards harnessing the potential of private monitoring initiatives, while consciously directing them towards dialoguing with and bolstering state capacity.

Trade agreements provide a central leverage point to create these programs because of opportunities pre and post-ratification to implement them. Trade agree- 
ments should condition their passage and tariff benefits on the implementation of experimental programs that have been shown to improve working conditions at the factory level. ${ }^{11}$ Over time, tariff benefits and perhaps other restrictive rules such as rules of origin can be liberalized depending on the degree of implementation or success of the supply chain labor institutions provided for. One could imagine granting the power to a third party, such as the ILO, to determine if the institutions have been implemented as required in the treaty.

A supply chain approach relies on governance based tools of monitoring, benchmarking, transparency, and competition. Institutional design should be variable and context contingent. One proposed model is an integrative approach (Kolben, 2007). In contrast to some governance based models, it prioritizes regulatory capacity building, and thus seeks to create and draw upon dialogic modes of interaction between private and public actors with the goal of mutual learning and improving the capacity of public regulatory institutions. A more complex iteration of a supply chain oriented labor chapter institution might require mechanisms of information gathering on factory labor conditions that would be made publicly available. The program would be directed by a master governance council at the top, and multiple local councils composed of various stakeholders. The local councils that would decide how to implement the labor provision's overall monitoring directives and remedial goals (Kolben, 2007, p. 248). Factory level compliance information would be collected and shared by competing private and public actors, who might use varying methodologies to collect information and address problems. ${ }^{12}$ The quality of those methodologies, as well as the performance of subsidiary councils, would in turn be evaluated by the master council or another supervisory body (Kolben, 2007, p. 250). The labor provision, for example, might call for a panel of experts to evaluate and compare the quality of different local monitoring initiatives, or delegate this task to the ILO.

A more simplified, and probably feasible, approach would be to require the implementation and funding of programs that already have strong track records, such as the Better Work program. Better Work found its start in a trade agreement between the US and Cambodia that required the implementation of an ILO-run program called Better Factories. Better Factories generated public information about conditions in Cambodian factories and made that information public, initially both to lead firms as well as to consumers and other stakeholders (Arnold \& Shih, 2010; Kolben, 2004; Oka, 2009, 2010; Polaski, 2009; Rossi \& Robertson, 2011). This transparency created an incentive for factories to improve regardless of state enforcement. Better Work has evolved to combine active consulting and advising of factories on labor practices, while also continuing its auditing and industry- wide transparency. It also brings multiple stakeholders into its governance, including governments, unions, and employers. (Kolben, 2015, p. 456) A number of scholars have found noted improvements in working conditions where Better Work has been implemented, including in Cambodia (Berik \& Rodgers, 2010, pp. 74-75; Rossi, 2015). Better Work has also been innovative in interacting with the state with the aim of improving enforcement of labor law by labor ministries, as has been demonstrated in case studies of its programs in Jordan and Indonesia (Dupper et al., 2016; Kolben, 2015).

The benefit of building a program like Better Work into a trade agreement, as it was in Cambodia, and potentially into its tariff and rule structure, is that it creates incentives for trading partners to fund and implement the programs sufficiently and sustainably. By linking programs, like Better Work, or other iterations, to actual rewards and benefits in the trade agreement context, it ensures that the parties take the obligations seriously, and it provides more leverage to build in opportunities for dialogue and cooperation with labor ministries and the state. For example, one could create a graduated tariff and non-tariff barrier reduction scheme, which would grant benefits to partner countries in a graduated manner only if they implement in good faith the supply chain improvement institutions described earlier.

Some might argue that a more tailored approach, such as the one suggested here, might be too limited. But as I have tried to suggest, extant labor chapter approaches have been too broadly targeted with mixed results. A tailored and governance centered approach would potentially have more leverage by drawing on the power of consumer citizens, and improving labor conditions in supply chains could then have positive spillover effects on other factories and industries not implicated in those chains, although how this occurs requires more examination (Weil \& Mallo, 2007). Further, a targeted approach might be considered to be more legitimate by trading partners. Rather than the labor chapter being viewed as a normative imposition by one state upon another, it would be seen as motivated by the demands and desires of consumer citizens grounded in the market, and facilitated by their governments. Others might also argue that given the mixed, if not poor, track record of private monitoring (Locke, 2013), that the approach proposed here might have no better prospects than the state oriented one that has been suggested to underperform, as well. But what is most novel about this approach is that it aims to integrate both public and private tools of enforcement that harness the influence of consumer citizens on lead firms. It is not a catchall solution, but rather part of the "mosaic" that constitutes transnational labor regulation (Trubek, Mosher, \& Rothstein, 2000, p. 1189). Finally, given the limited willingness by states to trigger dispute settlement processes, what makes this solution

\footnotetext{
11 Vogt (2015) has raised the question in his critiques of FTA labor provisions if they make concrete improvements at the workplace level.

12 Alternatively, there could be one "super monitor" whose track record is well proven, such as the ILO. Although this has its own limitations (Kolben, 2007, p. 249).
} 
any more useful? For one, dispute settlement would be diminished in importance, and thus states would have a smaller hand in the effective implementation of labor provisions. Second, power would be delegated to a neutral body such as the ILO to act as a super monitor, which would also decide if the labor chapter is being properly implemented, thus triggering tariff reductions.

\section{Conclusion}

This article has argued that the state action-state sanctions, and state action-social dialogue based models of the US and EU are limited in their ability to effect change in the labor conditions of trading partner countries. This has been true in practice, and I have suggested is a consequence of their design. Rather than aiming to change labor law enforcement in isolation from the factors that cause poor rule of law, this article has argued that labor provisions ought to be embedded in a supply chain approach that is informed by the legitimate drivers of trade and labor chapters, such as consumer citizenship, and that would satisfy expectations of fairness by domestic constituencies that would oppose trade liberalization where trading partners had low labor standards. Such an approach focuses not on exporting norms to trading partners by dialoguing or sanctioning poor labor law enforcement, nor on using sanctions, but instead on tailored and context specific interventions to improve labor standards in supply chains that are involved in international trade flows. In particular, it draws on regulatory innovations grounded in consumer citizenship and experimentalism that I have argued wield the potential to improve labor chapter effectiveness and improve the lives of workers in global supply chains.

\section{Acknowledgments}

The author would like to thank the editors of this volume, as well as the helpful comments of the reviewers. This paper also benefited from comments and critiques from participants at the New York University Law School's symposium, "Parsing the Trans-Pacific Partnership: The Implications of the Trade Deal for Human Rights, Labor", and the Economy, in November 2016, where a different version was presented.

\section{Conflict of Interests}

The author declares no conflict of interests.

\section{References}

Amengual, M., \& Chirot, L. (2016). Reinforcing the state transnational and state labor regulation in Indonesia. ILR Review, 69(5), 1056-1080.

Arnold, D., \& Shih, T. H. (2010). A fair model of globalisation? Labour and global production in Cambodia. Journal of Contemporary Asia, 40(3), 401-424.
Bartels, L. (2017). Human rights, labour standards and environmental standards in CETA. In S. Griller, W. Obwexer, \& E. Vranes (Eds.), Mega-regional agreements: TTIP, CETA, TISA. New orientations for EU external economic relations (pp. 202-215). Oxford: Oxford University Press.

Bartley, T., Koos, S., Samel, H., Setrini, G., \& Summers, N. (2015). Looking behind the label: Global industries and the conscientious consumer. Bloomington, IN: Indiana University Press.

Berik, G., \& Rodgers, Y. V. D. M. (2010). Options for enforcing labour standards: Lessons from Bangladesh and Cambodia. Journal of International Development, 22(1), 56-85.

Black, J. (2008). Constructing and contesting legitimacy and accountability in polycentric regulatory regimes. Regulation \& Governance, 2(2), 137-164.

Bolle, M. J. (2016). Overview of labor enforcement issues in free trade agreements (Congressional Research Service Report RS22823). Washington, DC: Congressional Research Service.

Brown, R. C. (2015). Fostering labor rights in a global economy: The efficacy of the emergent U.S. model trade and investment frameworks to advance international labor standards in Bangladesh. International Labour Review, 155(3), 383-406.

Campling, L., Harrison, J., Richardson, B., \& Smith, A. (2016). Can labour provisions work beyond the border? Evaluating the effects of EU free trade agreements. International Labour Review, 155(3), 357-382.

De Ville, F., Orbie, J., \& Van den Putte, L. (2016). TTIP and labour standards (Report prepared for European Parliament's Committee on Employment and Social Affairs). Brussels: European Parliament.

Dupper, O., Fenwick, C., \& Hardy, T. (2016). The interaction of labour inspection and private compliance initiatives: A case study of better work Indonesia (Better work discussion paper series: No. 21). Geneva: International Labour Organization.

Eckhardt, G. M., Belk, R., \& Devinney, T. M. (2010). Why don't consumers consume ethically? Journal of Consumer Behaviour, 9(6), 426-436.

Fairtrade International. (2016). Scope and benefits of fairtrade, seventh edition 2015. Fairtrade International 2015. Retrieved from https://www.fairtrade. net/fileadmin/user_upload/content/2009/resources /2015-Monitoring_and_Impact_Report_web.pdf

Giumelli, F., \& Van Roozendaal, G. (2016). Trade agreements and labour standards' clauses: Explaining labour standards developments through a qualitative comparative analysis of US free trade agreements. Global Social Policy, 17(1), 38-61.

Hainmueller, J., \& Hiscox, M. J. (2015). The socially conscious consumer? Field experimental tests of consumer support for fair labor standards (MIT Political Science Department Research Paper No. 2012-15). Retrieved from https://ssrn.com/abstract=2062435 
Hainmueller, J., Hiscox, M. J., \& Sequeira, S. (2015). Consumer demand for fair trade: Evidence from a multistore field experiment. Review of Economics and Statistics, 97(2), 242-256.

International Labor Organization. (2016). Handbook on assessment on labour provisions. ILO: Geneva.

Johnston, J. (2008). The citizen-consumer hybrid: Ideological tensions and the case of whole foods market. Theory and Society, 37(3), 229-270.

Kim, M. (2012). Ex ante due diligence: Formation of ptas and protection of labor rights. International Studies Quarterly, 56(4), 704-719.

Kolben, K. (2004). Trade, monitoring, and the ILO: Working to improve conditions in Cambodia's garment factories. Yale Human Rights and Development Law Journal, 7, 79-107.

Kolben, K. (2007). Integrative linkage: Combining public and private regulatory approaches in the design of trade and labor regimes. Harvard International Law Journal, 48(1), 203-256.

Kolben, K. (2013). Trade, development, and migrant garment workers in Jordan. Middle East Law and Governance, 5(1/2), 195-226.

Kolben, K. (2015). Dialogic labor regulation in the global supply chain. Michigan Journal of International Law, 36(3), 425-466.

Locke, R. M. (2013). The promise and limits of private power: Promoting labor standards in a global economy. Cambridge and New York, NY: Cambridge University Press.

Nicholls, A. (2010). Fair trade: Towards an economics of virtue. Journal of Business Ethics, 92(2), 241-255.

Oehri, M. (2015). Comparing US and EU labour governance 'near and far'-Hierarchy vs network? Journal of European Public Policy, 22(5), 731-749.

Oka, C. (2009). Accounting for the gaps in labour standard compliance: The role of reputation-conscious buyers in the cambodian garment industry. European Journal of Development Research, 22(1), 59-78.

Oka, C. (2010). Channels of buyer influence and labor standard compliance: The case of Cambodia's garment sector. Advances in Industrial and Labor Relations, 17, 153-183.

Orbie, J., \& Van den Putte, L. (2016). Labour rights in Peru and the EU trade agreement: Compliance with the commitments under the sustainable development chapter (Working Paper, Austrian Foundation for Development Research, No. 58). Vienna: Austrian Foundation for Development Research.
Orbie, R. G. (2011). Promoting labour standards through trade: Normative power or regulatory state Europe. In R. G. Whitman (Ed.), Normative power Europe empirical and theoretical perspectives (pp. 161-186). New York, NY: Palgrave Macmillan.

Polaski, S. (2009). Harnessing global forces to create decent work in Cambodia. Geneva: ILO.

Postnikov, E., \& Bastiaens, I. (2014). Does dialogue work? The effectiveness of labor standards in EU preferential trade agreements. Journal of European Public Policy, 21(6), 923-940.

Rogowski, R. A. (2013). Reflexive labour law in the world society. Cheltenham: Edward Elgar Publishing.

Rossi, A. (2015). Better work: Harnessing incentives and influencing policy to strengthen labour standards compliance in global production networks. Cambridge Journal of Regions, Economy, and Society, 8(3), 505-520.

Rossi, A., \& Robertson, R. (2011). Better factories Cambodia: An instrument for improving industrial relations in a transnational context (Working Paper 256). Washington, DC: Center for Global Development.

Sabel, C. F., \& Zeitlin, J. (2008). Learning from difference: The new architecture of experimentalist governance in the EU. European Law Journal, 14(3), 271-327.

Stolle, D., \& Micheletti, M. (2013). Political consumerism: Global responsibility in action. Cambridge: Cambridge University Press.

Trubek, D. M., Mosher, J., \& Rothstein, J. S. (2000). Transnationalism in the regulation of labor relations: International regimes and transnational advocacy networks. Law \& Social Inquiry, 25(4), 1187-1211.

Van Den Putte, L., \& Orbie, J. (2015). EU bilateral trade agreements and the surprising rise of labour provisions. International Journal of Comparative Labour Law and Industrial Relations, 31(3), 263-283.

Van Roozendaal, G. (2015). The diffusion of labour standards: The case of the US and Guatemala. Politics and Governance, 3(2), 18-33.

Vogt, J. S. (2015). The evolution of labor rights and trade-A transatlantic comparison and lessons for the transatlantic trade and investment partnership. Journal of International Economic Law, 18(4), 827-860.

Weil, D., \& Mallo, C. (2007). Regulating labour standards via supply chains: Combining public/private interventions to improve workplace compliance. British Journal of Industrial Relations, 45(4), 791-814.

\section{About the Author}

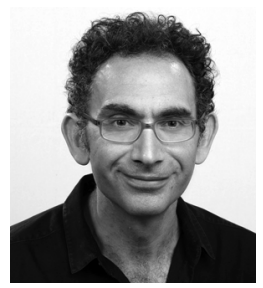

Kevin Kolben is an associate professor at Rutgers Business School in the Department of Supply Chain Management, and a core faculty member of the Rutgers Division of Global Affairs. His research focuses on trade, labor, and supply chain regulation. He currently serves as a member of the US Department of Labor's National Advisory Committee on Labor Provisions of Trade Agreements. He holds a JD and MA from the University of Michigan. 